\title{
THE STUDY OF CHEMICAL COMPOSITION AND EVALUATION OF GROUNDWATER QUALITY IN SOME REGIONS OF MOLDOVA
}

\author{
Mitina Tatyana, Bondarenco Nadejda, Bunciuc Oxana \\ Institute of Chemistry of the ASM, 3 Academiei str., Chisinau, Republic of Moldova \\ Email: mitina_tatiana@mail.ru, Tel: (37322)739977
}

\begin{abstract}
The paper presents the results of groundwater study from different sources, selected in v. Myndreshty, Telenesti district, in various villages of Cahul district and in artesian wells in and around Chisinau. Large differences were evidenced in water chemistry in different villages of one district, as well as within the same village. Was assessed thee compliance of analyzed water to quality requirements of drinking water.
\end{abstract}

Keywords: drinking water, wells, chemical composition, maximum allowable concentration.

\section{Introduction}

Drinking water must be chemically harmless, safe in epidemiological and radiation meanings, and have favorable organoleptic properties. Water quality is determined by a number of indicators, limiting concentrations of which are given by the relevant regulations. In Moldova, the quality requirements for drinking water are established by the Governmental Decision №.934 from 15.08.2007. This document is valid as an alternative to GOST 2874-82.

However, in our work to assess water quality by analyzing its chemical composition, we used both documents. This is due to the fact that some of the parameters are not reflected in the new document, or their maximum allowable concentrations are increased. For example, the content of allowable solids has increased from $1000 \mathrm{mg} / \mathrm{L}$ to $1,500 \mathrm{mg} / \mathrm{L}$, although the standard of physiological usefulness of water is $100-1000 \mathrm{mg} / \mathrm{L}$.

The world's first standard of the dry residue in water was adopted by the Brussels Commission in 1853. It was set $(500 \mathrm{mg} / \mathrm{L})$ on the basis of the average solids in the water reservoirs of Saxony-Weimar Duchy, which was considered benign in terms of organoleptic properties and did not cause disease in population. Since then, the idea of water quality has extended, but the standard of solids is still determined on the basis of organoleptic properties of water and the impact on public health.

When the content of dry residue exceeds $1000 \mathrm{mg} / \mathrm{L}$ the organoleptic properties of water perceived by the consumers are deteriorated. Mineral salts in great amounts give water a salty or bitter taste. Sodium and calcium chlorides are the main species that confer a salty taste, sulphates and chlorides of magnesium make it bitter. In addition, studies show that the use of highly mineralized water is harmful for the body: it can lead to frustration of many metabolic and biochemical processes and to development of various functional, as well as morphological disorders.

The content of strontium in the water is not regulated by the Governmental Decision № .934 from 15.08.2007, while according to GOST 2874-82 the strontium content must not exceed $7 \mathrm{mg} / \mathrm{L}$. The necessity of a strontium standard in the Country is due to the fact that its content in some areas of Moldova (Chisinau, Orhei district) is much higher than $7 \mathrm{mg} / \mathrm{L}$, and the presence of this element in the water is not safe for human health. Strontium excess affects bones, liver and brain. Being close to calcium by its chemical properties, strontium is very different from it in its biological action. An excess of this element in soil, water and food induces "the urov disease" in humans and animals (named after the river Urov In East Trans-Baikal region) - failure and deformation of the joints, growth retardation and other abnormalities. This pathology is a reflection of the competitive relationship of strontium and calcium in their distribution in the body.

As for the content of hardness inducing salts in water, according to GOST $2874-82$, it must not exceed $7 \mathrm{mgEq} / \mathrm{L}$ (or $7 \mathrm{~mol} / \mathrm{m}^{3}$ ), while the Governmental Decision № .934 from 15.08.2007 established only the lower limit of hardness -5 German degrees, which is equal to $1.79 \mathrm{mgEq} / \mathrm{L}$ or $1.79 \mathrm{~mol} / \mathrm{m}^{3}$, and the upper limit is not specified. The ratio of the physiological usefulness of water hardness ranges from 1.5 to $7 \mathrm{mgEq} / \mathrm{L}$.

The main source of centralized water supply in Moldova is the surface water of the rivers Dniester and Prut, and artesian wells. The rural population mainly uses groundwater as drinking water - wells and springs. River water resources consist of large rivers - the Prut and the Dniester - and small rivers. Chemical composition of river water is affected by anthropogenic factors; it varies significantly and may change depending on the season.

Groundwater, presented mainly in springs and wells, is characterized by a widely varied chemical composition, which depends on the geological and physical-chemical factors, as well as on anthropogenic factors. Groundwater in Moldova often doesn't match the requirements for drinking water regarding the content of hardness salts, sulfates, chlorides, sodium, ammonia, nitrite, nitrate, total soluble solids.

With regard to groundwater, its composition largely depends on the geological and physical-chemical factors. This 
explains the presence of high content of selenium, fluoride, strontium, hydrogen sulfide and ammonia in the groundwater of Moldova. Anthropogenic effects on underlying aquifers are minimal, and substances such as nitrates, pesticides and heavy metals can be hardly found there.

\section{Results and discussions}

This paper presents the results of a study of groundwater from different sources (wells and artesian wells) sampled in different regions of Moldova.

We studied 30 wells in v. Myndreshty, Telenesti district (figure 1), seven wells in various villages of Cahul district (table 1), and six artesian wells in and around Chisinau (table 2).
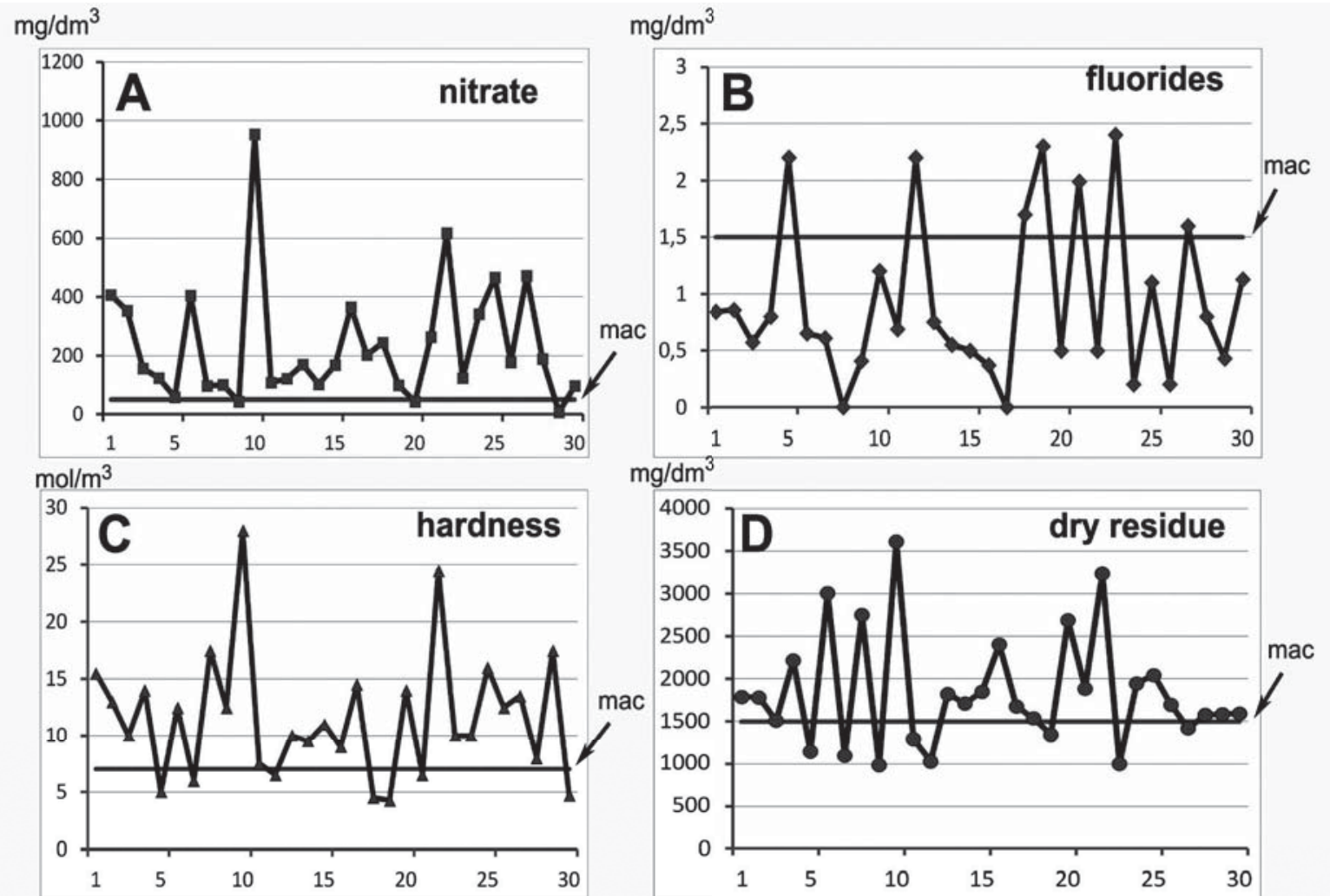

Fig.1. The results of determination of nitrates (A), fluorides (B), hardness (C) and dry residue (D) in the water of 30 wells in v. Myndreshty, Telenesti district

The abscissa shows the number of wells. Arrows indicate the maximum allowable concentration (mac) for each of the analyzed parameters. Figure 1 shows that the content of each of the analytes varies from well to well. Thus, the nitrate content varies from 6.6 to $953.8 \mathrm{mg} / \mathrm{dm}^{3}$. Fluoride ranges from $<0.2$ to $2.40 \mathrm{mg} / \mathrm{dm}^{3}$. Hardness varies from 4.25 to $28.0 \mathrm{~mol} / \mathrm{m}^{3}$, dry residue - from 990 to $3238 \mathrm{mg} / \mathrm{dm}^{3}$. Nitrate concentrations did not exceed the maximum allowable concentration in only three of the $30(10 \%)$ wells in v.Myndreshty.

In the rest of the wells, excess of concentration ranged from 2 to 18 times. Hardness does not exceed the maximum allowable concentration in eight (26,7\%) wells, dry residue - in $8(26,7 \%)$ wells and fluorides in $24(80 \%)$ wells.

If the dry residue is evaluated according to GOST 2874-82, only one well meets the requirements of the standard on the content of dry residue. Of the 30 wells analyzed, none of them meets the requirements of Governmental Decision № .934 for at least one of the four parameters. The content of strontium in these wells ranged from 0.57 to $4.40 \mathrm{mg} / \mathrm{dm}^{3}$, that does not exceed the maximum allowable concentration. These data suggest that even within the same locality one cannot conclude over the quality of water according to the analysis of one or two wells.

Table 1 presents the results of the analysis of water from wells in various villages of Cahul district.

Only one of seven wells (14\%) in various villages of Cahul district has concentration of nitrates not exceeding the maximum allowable concentration; hardness was greater than the required standards in all wells, and dry residue was in $5(71 \%)$. Concentration of ammonium exceeded the maximum allowable concentration in $3(60 \%)$ wells. In this case, no wells complied with the standard requirements. 
The content of some indicators of the Chemical composition of water in various villages of Cahul district

\begin{tabular}{|c|c|c|c|c|c|c|}
\hline \multirow[b]{2}{*}{ The sampling place } & \multicolumn{6}{|c|}{ Parameter and units of measurements } \\
\hline & 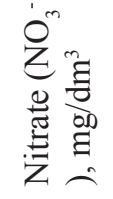 & 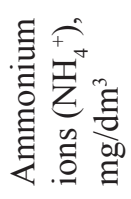 & 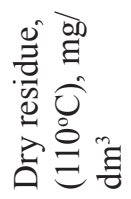 & 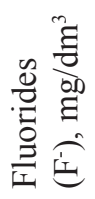 & 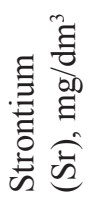 & 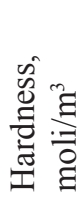 \\
\hline $\begin{array}{l}\text { Maximum allowable } \\
\text { concentration }\end{array}$ & 50 & 0,5 & 1500 & 1,5 & 7,0 & 7,0 \\
\hline v. Vadul lui Isac & 20,5 & 0,6 & 822 & $<0,2$ & 0,37 & 10,5 \\
\hline v.Valeni & 1476,0 & $\mathrm{n} / \mathrm{d}$ & 6173 & $<0,2$ & 1,75 & 58,0 \\
\hline v. Colibas & 336,4 & $\mathrm{n} / \mathrm{d}$ & 4011 & $<0,2$ & 1,0 & 38,5 \\
\hline v.Brinza & 174 & 0,24 & 785 & $<0,2$ & 0,62 & 12,3 \\
\hline v.Crihana Veche & 213,2 & 2,4 & 1723 & 0,4 & 1,50 & 24,5 \\
\hline v.Slobozia Mare & 361,8 & 1,8 & 1543 & 0,6 & 1,25 & 17,4 \\
\hline v.Manta & 171,5 & 0,3 & 1625 & 0,4 & 0,75 & 18,6 \\
\hline
\end{tabular}

Remark: $\mathrm{n} / \mathrm{d}$ - indices that were not determined.

Table 2 shows the results of determination of several chemical indexes in six artesian wells in and around Chisinau.

Table 2

The content of some indicators of the chemical composition of water in six artesian wells in and around Chisinau

\begin{tabular}{|c|c|c|c|c|c|c|c|c|}
\hline 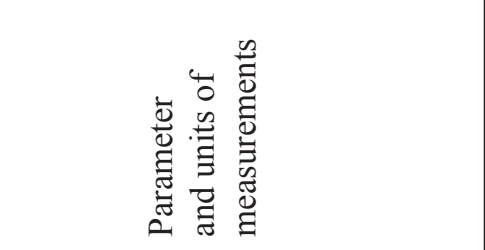 & 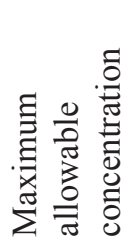 & 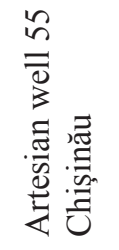 & 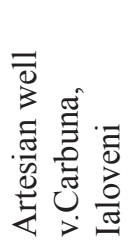 & 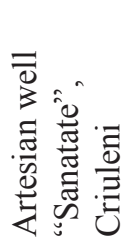 & 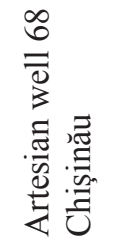 & 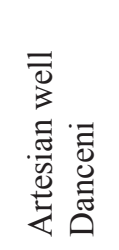 & 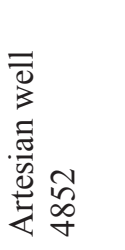 & $\begin{array}{l}\frac{\pi}{Z} \\
0 \\
Z \\
\tilde{z} \\
0 \\
0 \\
0 \\
\tilde{U}\end{array}$ \\
\hline Hardness, $\mathrm{mol} / \mathrm{m}^{3}$ & 7,0 & 17,51 & 2,65 & 2,09 & 44,67 & 2,13 & 16,8 & \\
\hline Dry residue, $\left(110^{\circ} \mathrm{C}\right), \mathrm{mg} / \mathrm{dm}^{3}$ & 1500 & 1377 & 573,5 & 796,5 & 6500 & 610 & 1149 & \\
\hline Nitrate $\left(\mathrm{NO}_{3}^{-}\right), \mathrm{mg} / \mathrm{dm}^{3}$ & 50,0 & $<0,4$ & $<0,4$ & $<0,4$ & $<0,4$ & $<0,4$ & $<0,4$ & \\
\hline Nitrite $\left(\mathrm{NO}_{2}^{-}\right), \mathrm{mg} / \mathrm{dm}^{3}$ & 0,5 & 0,03 & $<0,01$ & 0,06 & $<0,01$ & $<0,01$ & $<0,01$ & \\
\hline Ammonium ions $\left(\mathrm{NH}_{4}^{+}\right), \mathrm{mg} / \mathrm{dm}^{3}$ & 0,5 & 4,38 & 1,97 & 2,2 & 1,9 & 4,2 & 0,7 & \\
\hline Fluorides $\left(\mathrm{F}^{-}\right), \mathrm{mg} / \mathrm{dm}^{3}$ & 1,5 & 0,21 & 1,0 & 2,65 & 0,5 & $<0,2$ & 0,6 & \\
\hline Iron total $(\mathrm{Fe}), \mathrm{mg} / \mathrm{dm}^{3}$ & 0,3 & 0,25 & 0,3 & 0,62 & - & 0,3 & 0,29 & \\
\hline Hydrogen sulfide $\left(\mathrm{H}_{2} \mathrm{~S}\right), \mathrm{mg} / \mathrm{dm}^{3}$ & 0,1 & 2,22 & 0,42 & - & - & - & 0,57 & \\
\hline Sulfates $\left(\mathrm{SO}_{4}^{-2}\right), \mathrm{mg} / \mathrm{dm}^{3}$ & 250 & 553,5 & 143,8 & 121,5 & 1547,7 & 163 & 388,1 & \\
\hline Chlorides $\left(\mathrm{Cl}^{-}\right), \mathrm{mg} / \mathrm{dm}^{3}$ & 250 & 85,2 & 35,5 & 56,8 & 2566,6 & 46,6 & 66,6 & \\
\hline Strontium $(\mathrm{Sr}), \mathrm{mg} / \mathrm{dm}^{3}$ & 7,0 & 13,3 & 1,1 & 1,4 & 25 & 1,2 & 5,1 & \\
\hline Selenium $(\mathrm{Se}), \mathrm{mg} / \mathrm{dm}^{3}$ & 0,01 & $<0,005$ & $<0,005$ & $<0,005$ & $<0,005$ & $<0,005$ & $<0,005$ & \\
\hline Zinc $(\mathrm{Zn}), \mathrm{mg} / \mathrm{dm}^{3}$ & 3,0 & $<0,1$ & $<0,1$ & $<0,1$ & $<0,1$ & $<0,1$ & $<0,1$ & \\
\hline Copper $(\mathrm{Cu}), \mathrm{mg} / \mathrm{dm}^{3}$ & 1,0 & $<0,1$ & $<0,1$ & $<0,1$ & $<0,1$ & $<0,1$ & $<0,1$ & \\
\hline Molybdenum (Mo), $\mathrm{mg} / \mathrm{dm}^{3}$ & 0,25 & $<0,01$ & $<0,01$ & $<0,01$ & $<0,01$ & $<0,01$ & $<0,01$ & \\
\hline Manganese $(\mathrm{Mn}), \mathrm{mg} / \mathrm{dm}^{3}$ & 0,05 & $<0,01$ & $<0,01$ & $<0,01$ & $<0,01$ & $<0,01$ & $<0,01$ & \\
\hline
\end{tabular}

The analysis of water in six artesian wells in the general evidence a higher quality of water from artesian wells compared to water from wells. The content of nitrate, nitrite, selenium, zinc, copper, molybdenum and manganese do not exceed the maximum allowable concentrations in all samples. However, the concentration of ammonium ions exceeds the maximum permissible concentration in all artesian wells, and the concentration of hydrogen sulfide in all studied wells. 


\section{Conclusions}

The data indicate that only part of Moldova's population has access to safe drinking water. All analyzed water from wells and artesian wells requires additional treatment before reaching the consumer.

\section{References}

[1]. Rukovodstvo po obespečeniy kačestva pitьevoi vody t.1. Rekomendacii. Vsemirnaя Organizaciя zdravoohraneniy. Geneva 2004 g.

[2]. GOST 2874-82 Voda pitьevar. Gigieničeskie trebovaniя i kontrols za kačestvom, Moskva.

[3]. SanPiN 2.1.4.1116-02 Рitievaя voda. Gigieničeskie trebovaniя k kačestvu vody, rasfasovannoi v emkosti. Kontroli kačestva.Sanitarno-эpidemiologičeskie pravila i normativy, Minzdrav Rossii, Moskva 2002.

[4]. SM SR ISO 8288:2006 Calitatea apei. Determinarea conținutului de cobalt, nichel, cupru, zinc, cadmiu şi plumb. 